\title{
Review
}

\section{The Alzheimer's Disease Mitochondrial Cascade Hypothesis}

\author{
Russell H. Swerdlow ${ }^{\mathrm{a}, *}$, Jeffrey M. Burns ${ }^{\mathrm{a}}$ and Shaharyar M. Khan ${ }^{\mathrm{b}}$ \\ ${ }^{a}$ Departments of Neurology and Molecular and Integrative Physiology, University of Kansas School of Medicine, \\ Kansas City, KS, USA \\ ${ }^{\mathrm{b}}$ Gencia Corporation, Charlottesville, VA, USA
}

Accepted 5 April 2010

\begin{abstract}
We first proposed the mitochondrial cascade hypothesis of sporadic Alzheimer's disease (AD) in 2004. Our core assumptions were a person's genes determine baseline mitochondrial function and durability, this durability determines how mitochondria change with advancing age, and critical changes in mitochondrial function initiate other pathologies characteristic of AD. Since then several lines of investigation report data consistent with or supportive of our hypothesis. In particular, $\mathrm{AD}$ endophenotype studies suggest a strong maternal genetic contribution, and links between mitochondrial function, tau phosphorylation, and amyloid- $\beta(\mathrm{A} \beta)$ amyloidosis are increasingly recognized. As predicted, AD therapies designed to reduce $\mathrm{A} \beta$ thus far have had at best very limited clinical benefits; our hypothesis identifies alternative therapeutic targets. While placing mitochondria at the apex of an AD cascade certainly remains controversial, it is increasingly accepted by the AD research community that mitochondria play an important role in the late-onset forms of the disease. Even if the mitochondrial cascade hypothesis proves incorrect, considering its assumptions could potentially advance our understanding of sporadic, late-onset AD.
\end{abstract}

Keywords: Alzheimer's disease, amyloid- $\beta$, cytochrome oxidase, endophenotype, mitochondria, mitochondrial DNA

\section{EXISTING ALZHEIMER'S DISEASE HYPOTHESES}

For almost twenty years the amyloid cascade hypothesis has dominated Alzheimer's disease (AD) thinking, modeling, and therapeutic development efforts [1]. Briefly, it proposes sufficient accumulation of an amyloid- $\beta$ protein precursor $(\mathrm{A} \beta \mathrm{PP})$ derivative, amyloid- $\beta(\mathrm{A} \beta)$, induces the salient biochemical, histologic, and clinical changes AD patients manifest [2]. It has evolved over time; the most important conceptual refinements relate to what particular form of $\mathrm{A} \beta$ is felt to occupy the disease pyramid's apex. Currently,

*Correspondence to: Russell H. Swerdlow, MD, University of Kansas School of Medicine, MS 2012, Landon Center on Aging, 3901 Rainbow Boulevard, Kansas City, KS 66160, USA. Tel.: +1913 588 6970; Fax: +1 913945 5035; E-mail: rswerdlow@kumc.edu. oligomers consisting of the 42 amino acid $\mathrm{A} \beta$ derivative $\left(\mathrm{A} \beta_{42}\right)$ are believed to be critical [3].

The amyloid cascade hypothesis was formulated after an $\mathrm{A} \beta \mathrm{PP}$ mutation was reported in a family with autosomal dominant amyloid angiopathy, dementia, and AD-typical histology [4]. Two other genes, presenilin (PS) 1 and 2, also contain mutations in autosomal dominant $\mathrm{AD}$ and the presenilin proteins are reportedly part of the $\gamma$-secretase complex that processes A $\beta$ PP [5-8]. In autosomal dominant $\mathrm{AD}$, mutations in each of these proteins are believed to shift $\mathrm{A} \beta \mathrm{PP}$ processing towards $\mathrm{A} \beta_{42}$ [9].

This hypothesis has been extrapolated to sporadic AD. Sporadic AD patients do not have A $\beta$ PP or PS mutations, so the cause of excessive $\mathrm{A} \beta_{42}$ production in sporadic $\mathrm{AD}$ is unknown [10]. It is presumed, though, that $\mathrm{AD}$ patients have gene variations that subtly steer $\mathrm{A} \beta \mathrm{PP}$ processing towards $\mathrm{A} \beta_{42}$. 


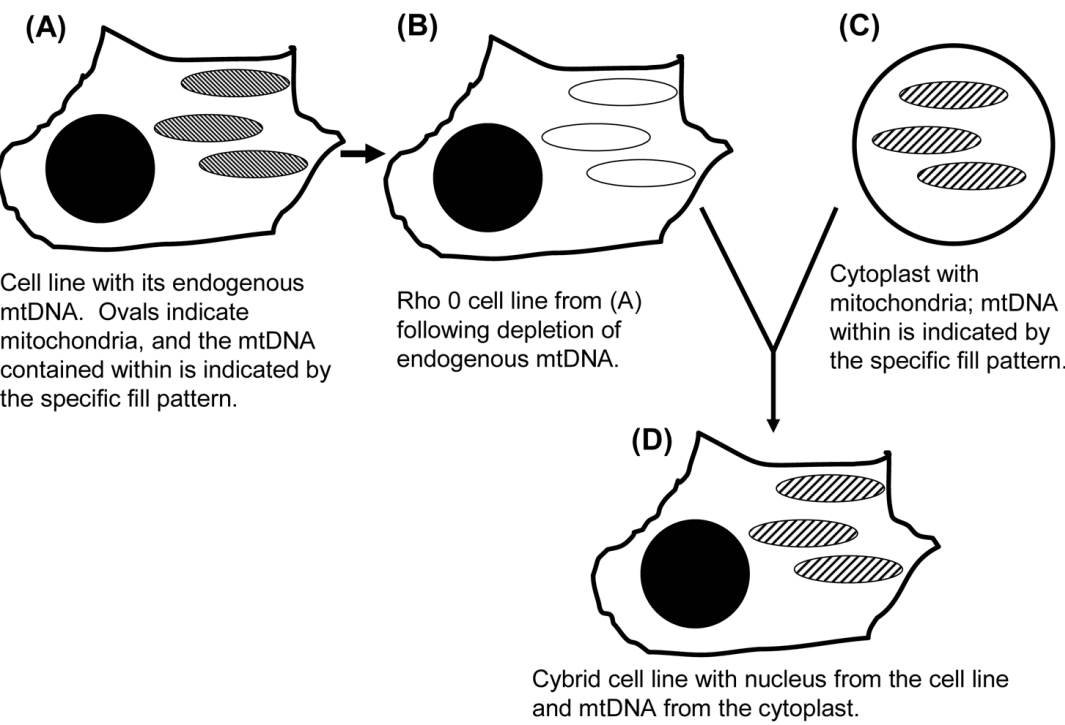

Fig. 1. The cybrid technique. A cultured cell line (A) is depleted of endogenous mtDNA to create $\rho 0$ cells (B). Cytoplasts containing mitochondria (C) but not nuclei are mixed with $\rho 0$ cells in the temporary presence of a detergent that disrupts cell membranes. When cell membranes reform, mixing $\rho 0$ cell and cytoplast contents produces cells with a $\rho 0$ cell line nucleus, cytoplast mitochondria, and cytoplast mtDNA (D).

Other AD hypotheses exist but none have enjoyed the influence of the amyloid cascade hypothesis. Tau, prion, and environmental causes have all been proposed to initiate $\mathrm{AD}$ and mediate progression [11-13]. Some believe oxidative stress, either by itself or as part of a "two hit process", causes AD [14]. In 2004 we proposed the mitochondrial cascade hypothesis, which attempts to explain how and why sporadic AD develops $[15,16]$.

\section{OVERVIEW OF THE MITOCHONDRIAL CASCADE HYPOTHESIS}

\section{Perceived need for the hypothesis}

We first proposed the mitochondrial cascade hypothesis in 2004 [15]. It arose through efforts to understand $\mathrm{AD}$ phenomena that, at least as far as we were concerned, were not readily accounted for by the amyloid cascade hypothesis. We wanted to understand the cause or causes of $\mathrm{A} \beta$ amyloidosis in sporadic $\mathrm{AD}$ patients. We sought a clearer explanation for the continuous correlation between advancing age and AD risk. Also, much of our own research at that time leveraged the fact that AD patients have specific systemic biochemical features. To date, the amyloid cascade hypothesis has done little to address the fact that on a biochemical level, $\mathrm{AD}$ is not a brain-limited condition.

\section{$A D$ mitochondrial perturbations and cybrid modeling of $A D$ mitochondrial function}

Our mitochondrial cascade hypothesis was heavily influenced by our own work on the causes and consequences of AD-related mitochondrial dysfunction. It is important to emphasize we were by no means the first to describe mitochondrial perturbations in AD patients. For decades it was known that mitochondrial morphology is altered in AD subject brains. Deficiencies of two Krebs cycle enzymes, pyruvate dehydrogenase complex and ketoglutarate dehydrogenase complex, were reported in the 1980s [17-19]. Reduced AD subject cytochrome oxidase activity was first reported in 1990 [20]. The AD cytochrome oxidase defect was first demonstrated in AD subject platelet mitochondria, and later shown to occur in the AD brain [21,22].

During the 1990s we used a cytoplasmic hybrid (cybrid) approach [23] to address whether mitochondrial DNA (mtDNA) could at least partly account for the systemic AD cytochrome oxidase defect (Fig. 1). Cytochrome oxidase, or complex IV of the electron transport chain (ETC), is a 13 subunit multimeric protein localized to the mitochondria inner membrane. Ten subunits are encoded on nuclear genes and imported into the mitochondrial inner membrane. Three subunits are encoded on mtDNA, and these are the most catalytically important subunits. We isolated platelets from $\mathrm{AD}$ and age-matched control subjects and fused those platelets with both human neuroblastoma SH-SY5Y cells and 
human NT2 teratocarcinoma cells depleted of their endogenous mtDNA [24,25]. The mtDNA-depleted cells, also called $\rho 0$ cells, lack functional ETCs and are not respiration-competent because they cannot produce mtDNA-encoded ETC subunits. After accomplishing platelet mitochondrial transfer to the $\rho 0$ cells, the resulting cybrid cell lines became respiration-competent, but differences between cybrid cell lines that incorporated AD subject mitochondria and cybrid cell lines that incorporated control subject mitochondria were evident. In the $\mathrm{AD}$ cybrid cell lines, the cytochrome oxidase activity $\mathrm{V}_{\max }$ activity was lower, free radical production and oxidative stress markers were elevated, calcium homeostasis was altered, stress signaling pathways were activated, the mitochondrial membrane potential was reduced, apoptosis pathways were activated, and $\mathrm{A} \beta_{42}$ production was increased [26].

Based on these data we concluded that at least in a cybrid model system, AD subject mitochondria promote several abnormalities observed in AD subject brains. Our findings further suggested mtDNA at least partly accounts for the AD-associated cytochrome oxidase activity reduction [24]. This is because cybrid cells repeatedly divide in culture flasks, so any non-perpetuating material transferred from platelets degrades and dilutes over time. The biochemical endpoints listed above were present after months in culture and mtDNA is the only recognized perpetuating entity we transferred. Also, in $\mathrm{AD}$ subjects, plasma $\mathrm{A} \beta$ levels are lower than they are in control subjects [27]. This argues transfer of peripheral $\mathrm{A} \beta$ was not responsible for reduced $\mathrm{AD}$ cybrid cell line cytochrome oxidase activities.

\section{Clinical contributions to the hypothesis}

A phenomenon of age-related cognitive change has long been recognized [28]. For decades it was felt that in the absence of dementia, age-related cognitive change does not predict future AD. In the 1990s this perspective began to change. Non-demented individuals with clinically detectable cognitive domain weaknesses are now routinely characterized as having a mild cognitive impairment (MCI) syndrome. Those given an MCI diagnosis have a substantial chance of receiving a future AD diagnosis. Similarly, cognitive complaints that are unaccompanied by signs (subjective cognitive impairment; SCI) may portend an increased AD risk [29]. The obvious implication is that $\mathrm{AD}$ evolves throughout adulthood.

Epidemiologic studies further suggest a majority of persons have the capacity to develop AD should they live long enough. More than half of centenarians meet dementia syndrome criteria, and most have enough senile plaque and neurofibrillary tangle pathology to qualify for an AD diagnosis [28]. Sporadic AD incidence increases with advancing age and prevalence appears to rise at least through the ninth decade and probably beyond [30-32]. To us this suggests common factors drive both aging and AD. The amyloid cascade hypothesis would have to explain this relationship from the perspective that amyloidosis drives aging. Our assumption is that the reverse relationship, that aging drives amyloidosis, is more likely.

$\mathrm{AD}$ is currently defined as all plaque-and-tangle dementias [33]. This broad definition is based more on tactics than science. It is presumptuous to assume AD is a homogeneous condition. The simple presence of plaques and tangles does not prove dementing Down's syndrome patients, young adults with autosomal dominant family histories, and elderly individuals have a common etiology.

Many non-demented elderly individuals also have plaques and tangles [28,34]. Some propose such individuals have very early AD in which detectable dementia has not yet manifested [35,36]. Even if this is correct, though, correlation does not establish causality. After all, all persons with myocardial infarctions have elevated serum troponin, but troponin elevation does not cause myocardial infarction.

\section{Core assumptions of the hypothesis}

The mitochondrial cascade hypothesis (Fig. 2) proposes a person's genes determine their baseline mitochondrial function and mitochondrial durability $[15$, 16]. Nuclear and mtDNA genes probably contribute to this. Both parents influence one's lifetime AD risk, but because mtDNA is maternally inherited, mothers have a greater impact than fathers.

It is generally accepted that mitochondrial function declines with age, and data suggest this drives a variety of age-associated physiologic changes [37,38]. It is likely cell physiology initially compensates for and adapts to this change, but eventually a point is reached at which adequate compensation is no longer possible. The mitochondrial cascade hypothesis proposes a person's genetically determined mitochondrial starting line, in conjunction with their genetically and environmentally determined rate of mitochondrial decline, determines the age at which clinical disease ensues.

We propose that some histology changes typical of $\mathrm{AD}$ begin to manifest during the compensation phase 


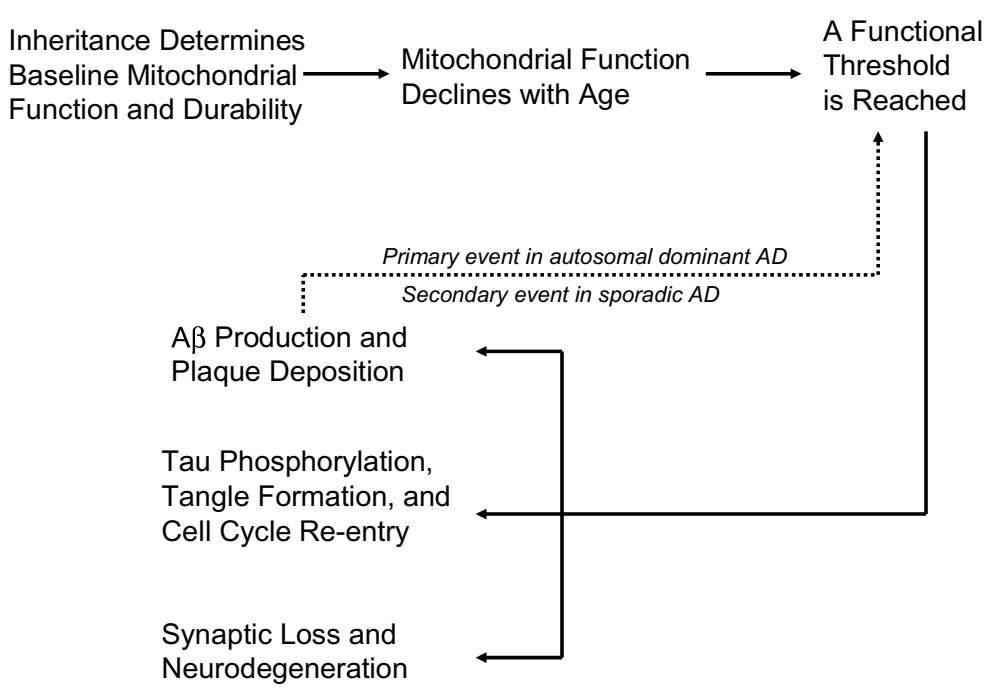

Fig. 2. The mitochondrial cascade hypothesis. In our hypothesis, which applies to sporadic AD, mitochondria are at the apex of the cascade. In autosomal dominant cases we also predict mitochondria may mediate the effects of presenile brain amyloidosis. Used with permission from reference [16].

and arise as a consequence of the compensation response. Other histology changes likely arise after compensation becomes inadequate and are a consequence of failed compensation. Phenomena that occur either during the mitochondrial compensation or failure phases include $\mathrm{A} \beta$ production, tau phosphorylation, synaptic loss, cell cycle re-entry, and neurodegeneration.

\section{DATA RELEVANT TO THE MITOCHONDRIAL CASCADE HYPOTHESIS}

\section{Genes determine baseline mitochondrial function and durability}

Late onset AD typically demonstrates neither clearcut Mendelian nor maternal inheritance [28]. It is generally considered a sporadic disorder, but this does not mean genes and inheritance are etiologically irrelevant. Whether an individual's parents develop AD does influence the chance of developing AD. For this reason, sporadic AD has occasionally been referred to as a pseudo-sporadic disease. The discussion below refers to late-onset sporadic or pseudo-sporadic $\mathrm{AD}$, not to autosomal dominant AD.

In 1990, Parker and colleagues proposed mtDNA inheritance could influence if not cause late onset AD [20]. The authors postulated mtDNA heteroplasmy and mitotic segregation would allow late-onset AD to present as a sporadic rather than a maternally inherited disorder. This was not entirely consistent with avail- able epidemiologic data indicating both parents contribute to their children's lifetime AD risk [39], but by the mid 1990s several studies reported among late onset $\mathrm{AD}$ subjects who report an $\mathrm{AD}$-affected or demented parent, the affected parent is more often a mother [40, 41]. This phenomenon persists after correcting for increased female longevity and higher rates of AD among women [40]. For late-onset AD, epidemiologic data suggest $\mathrm{AD}$ mothers contribute more to $\mathrm{AD}$ risk than $\mathrm{AD}$ fathers.

Several factors complicate the evaluation of intergenerational relationships in late-onset AD. There is some degree of diagnostic uncertainty in persons included in these studies. This uncertainty increases for the parental generation, which cannot be examined and who may have been diagnosed by criteria different to those now used. It is possible some parents diagnosed with $\mathrm{AD}$ may not have had AD. It seems more likely, though, that $\mathrm{AD}$ would have been under-appreciated in the parental generation. Prior to the 1970s, senile dementia was not typically considered to represent AD, and whether or not someone develops AD highly depends on how long they live. Persons at high AD risk that die at relatively young ages are not classified as having $\mathrm{AD}$, while persons with very low $\mathrm{AD}$ risk that live to advanced ages may acquire an $\mathrm{AD}$ diagnosis.

To minimize these limitations, some investigators now study $\mathrm{AD}$ endophenotypes in persons with an $\mathrm{AD}$ parent. An endophenotype is a disease feature or biomarker that can be ascertained in unaffected or undiagnosed persons. For a disease being studied, en- 
dophenotype carriers may have an increased risk of developing the disease, may be in the very early stages of developing a disease, or may have an incomplete form of the disease but will never advance to the actual disease. Endophenotypes may be genetically determined. The presence of an endophenotype state in an individual implies that individual inherited at least some degree of genetic risk. Several recent AD endophenotype studies are summarized below.

Positron emission tomography (PET) uses various ligands to assess brain functional or structural parameters. One ligand, a fluoro-labeled glucose analog called fluoro-2-deoxy-D-glucose (FDG), shows differences between $\mathrm{AD}$ and control subject brain glucose utilization [42]. In this PET application, FDG is injected intravenously. Some of the injected FDG enters the brain and some of this is phosphorylated by the enzyme hexokinase. Phosphorylated FDG is retained in the brain and un-phosphorylated FDG diffuses out. By determining rates of brain FDG import (K1), brain FDG egress (K2), and FDG phosphorylation (K3), it is possible to calculate a cerebral metabolic rate of glucose (CMRglu) utilization. Mosconi and colleagues used PET to study AD endophenotypes in middle-aged individuals without an AD diagnosis [43]. Subjects were divided into three groups, those with an AD mother (maternal family history, FHm), those with an AD father (paternal family history, FHp), and those in which neither parent developed AD (no family history, FH-). Relative to FH- subjects, FHp subjects showed very limited regional CMRglu declines. Relative to $\mathrm{FH}$ - and FHp subjects, FHm subjects showed CMRglu reductions in a number of brain regions including the hippocampus. This study concluded a maternally inherited genetic factor disposes persons to AD-like reductions in CMRglu utilization. A follow-up study performed over a 2 year period also found FHm subjects showed greater longitudinal CMRglu reductions than $\mathrm{FH}$ - or FHp subjects [44].

Voxel based morphometry (VBM) is a technique for determining relative regional brain volumes from brain magnetic resonance imaging (MRI) scans of individual subjects. We recently used VBM to analyze MRI scans from non-demented elderly individuals reporting FHm, FHp, and FH- AD family histories [45]. Relative to FH- subjects FHp subjects showed very limited regional volume reductions, while FHm subjects showed extensive volume reductions when compared to either group. Although APOE status can affect regional brain volumes, in this study APOE status was not responsible for VBM reductions unique to the FHm group. From this study we concluded for persons with an AD parent, a maternally inherited genetic factor predisposes to or is responsible for regionally specific brain volume reductions.

Pittsburgh Compound B (PIB) is a PET ligand that binds brain amyloid deposits [46]. Mosconi et al. analyzed PIB PET scans from middle aged individuals with FHm, FHp, and FH- AD family histories [47]. Relative to FH- subjects, FHp subjects showed very limited regional PIB increases, while FHm subjects showed extensive increases when compared to either group. This study concluded for persons with an AD parent, a maternally inherited genetic factor predisposes to or is responsible for brain amyloid deposition.

Debette et al. analyzed cognitive test performance in middle aged subjects from the Framingham Longevity study [48]. This is a well-defined, longitudinal cohort in which various age-relevant parameters are regularly characterized. The investigators grouped cognitive test data in various ways and found among APOE4 carriers, FHp and FH- test scores were equivalent. On two measures of memory, logical memory and visual reproduction, FHm scores were lower than those from FHsubjects. While the authors were very cautious in their interpretations, this study infers a maternally inherited, AD-associated genetic factor influences mid-life memory performance.

The epidemiologic and endophenotype studies discussed above suggest an individual's risk of developing sporadic or pseudosporadic, late-onset AD is influenced by whether either of their parents developed lateonset $\mathrm{AD}$. The mother's status, though, has a greater impact. For several reasons we previously postulated cytochrome oxidase may contribute to this uneven parental affect [16]. Cytochrome oxidase is unequally inherited; ten cytochrome oxidase subunit genes are bi-parentally inherited on nuclear chromosomes, and three catalytically relevant subunits are strictly maternally inherited via mtDNA. Cytochrome oxidase activity is systemically lower in AD subjects than it is in age-matched controls [22]. While a systemic increase in body $\mathrm{A} \beta$ levels could cause this, in $\mathrm{AD} \mathrm{A} \beta$ levels actually drop in some tissues [27]. Because of this, even though in vitro studies have shown $\mathrm{A} \beta$ inhibits cytochrome oxidase activity $\mathrm{A} \beta$-induced inhibition is unlikely to be the sole cause. Cybrid studies suggest at least part of the AD cytochrome oxidase defect is a consequence of mtDNA encoding [24,26]. While somatic mtDNA damage within the brain likely contributes to brain mitochondrial dysfunction, cybrid cell lines containing platelet mtDNA from AD subjects ar- 


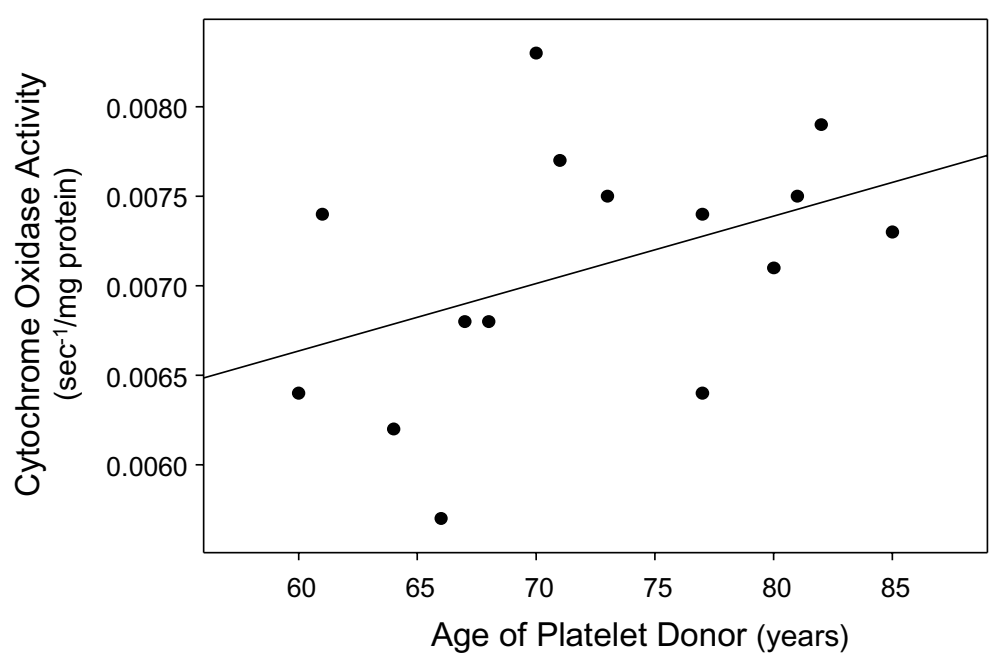

Fig. 3. Relationship between platelet donor age and cytochrome oxidase activity in AD cybrid cell lines. Younger platelet donors likely have a younger age of AD onset than older platelet donors. Cybrid cell lines made using platelets from younger AD subjects tend towards lower cytochrome oxidase $\mathrm{V}_{\max }$ activities. Used with permission from reference [16].

gues mtDNA inheritance constitutes an AD risk factor. For a series of AD cybrid cell lines we produced on an NT2 nuclear background, cybrid cell lines containing platelet mtDNA from younger donors tended to have a lower cytochrome oxidase activity than cybrid cell lines containing platelet mtDNA from older donors (Fig. 3) [10]. If somatic mtDNA mutation acquisition was driving the AD cybrid cytochrome oxidase activity reduction the opposite relationship would be expected.

To determine the extent of cytochrome oxidase gene variation in the general population, we sequenced 13 cytochrome subunit genes from 50 control subjects [49]. 27 of these 50 subjects had all 13 genes sequenced. When non-synonymous open reading frame (ORF), synonymous ORF, and untranslated region (UTR) polymorphisms were considered, none of these 27 individuals had identical genotypes. Because much nuclear-encoded cytochrome oxidase subunit gene variation was determined by UTR polymorphisms, we studied the impact of a common AGCCCC hexanucleotide deletion found in the COX7A1 5'UTR region. This deletion forms part of an AGCCCC repeat that constitutes an Sp1 binding site. We used a transcription reporter system to see whether the COX7A1 5'UTR AGCCCC deletion affected gene expression. When COX7A1 5'UTR wild type and deletion variants were inserted directly upstream of a green fluorescent protein ORF, the deletion variant produced less fluorescence than the wild type variant. This suggests cytochrome oxidase gene polymorphisms do not need to change amino acids to have functional consequences.
Synonymous polymorphisms were frequently found in the mtDNA COX1, COX2, and COX3 genes. Whether or not synonymous mtDNA polymorphisms are functionally relevant is unknown. Synonymous mtDNA polymorphisms were more frequent in the less conserved COX3 gene than they were in the more conserved COX1 gene, which could indicate even synonymous polymorphisms experience some degree of selection pressure. If so, even synonymous mtDNA cytochrome oxidase polymorphisms may influence cytochrome oxidase function [49].

When just non-synonymous polymorphisms were considered there was still a large degree of interindividual variation. One common nuclear cytochrome oxidase non-synonymous polymorphism was found, a $\mathrm{G}$ to A substitution in the COX4I1 gene that changes an alanine to a threonine. It was seen in $12 \%$ of subjects, and functional studies revealed expression of the COX4I1 substitution reduced cytochrome oxidase holoenzyme activity. The majority of the nonsynonymous polymorphisms, though, were found in mtDNA COX genes. While no single predominant polymorphism occurred, $20 \%$ of individuals had a nonsynonymous mtDNA COX gene substitution [49].

To summarize this section, AD endophenotypes may develop long before AD symptoms and signs. If correct, a maternally inherited genetic factor preferentially influences this. Maternal inheritance can occur with $\mathrm{X}$ chromosome inheritance, maternal gene imprinting, and mtDNA inheritance. X-chromosome inheritance seems less likely because it preferentially predisposes 
males to disease and in $\mathrm{AD}$ an increased male incidence is simply not observed. Cybrid studies are consistent with mtDNA inheritance.

\section{Age-related mitochondrial changes are potentially exaggerated in $A D$}

It is generally accepted that mitochondrial function declines with age [37]. Complex I and IV $\mathrm{V}_{\max }$ activities fall, but the complex II $\mathrm{V}_{\max }$ activity does not. Complex I and IV have mtDNA encoded subunits but complex II is entirely nuclear-encoded. This has led some investigators to speculate somatic mtDNA mutation contributes to age-related declines in mitochondrial function, and available data support this view [38, 50].

Young control, elderly control, and late-onset AD autopsy brains were evaluated for homoplasmic and heteroplasmic COX2 gene mutations [51]. Lowabundance heteroplasmic mutation frequencies from both elderly control and elderly AD brains exceeded levels in brains from young subjects. The cytochrome oxidase $\mathrm{V}_{\max }$ activity inversely correlated with the mutation burden; the more mutations there were, the lower the $\mathrm{V}_{\max }$ was. Mutation frequencies were comparable between $\mathrm{AD}$ and the age-matched control subjects.

Frequencies of other somatic mutations may differ between AD and age-matched control brains. Mutation levels of heteroplasmic, presumably somatic mtDNA control region mutations were elevated in $\mathrm{AD}$ subject brains [52]. Relative to age-matched control brains, mtDNA deletion levels are elevated in AD subject brains [53,54]. The majority of these deletions involve mtDNA COX genes. Increased mtDNA deletion abundance has also been demonstrated in Parkinson's disease substantia nigra and is believed by some to contribute to that neurodegenerative disease $[55,56]$.

Hirai and colleagues performed a detailed immunochemical and electron microscopy characterization of AD brain tissue [57]. Neuron mitochondrial mass increased during aging, and this increase persisted during AD. Many AD brain mitochondria, though, were found in various states of disrepair and lysosomal degradation. AD neurons overall had fewer normal appearing mitochondria. Mitochondria in AD neurons also contained higher levels of the common $5 \mathrm{~kb}$ mtDNA deletion. When degrading mitochondria were considered in the analysis, AD neurons contained more total $\mathrm{mtD}$ NA and more COX1 protein than control neurons. The amount of normal mtDNA present within intact mitochondria, though, was diminished. Other investigators have found $\mathrm{AD}$ brains contain less PCR-amplifiable mtDNA than control brains, which also suggests levels of retrievable, intact mtDNA are reduced in AD brains [58,59].

\section{Mitochondrial function influences AD histology}

Data indicate mitochondria influence tau phosphorylation and $\mathrm{A} \beta \mathrm{PP}$ processing. Tau phosphorylation increases in rats and cultured neurons exposed to ETC inhibitors [60-62]. Treating cells with sodium azide, a cytochrome oxidase inhibitor, shifts $\mathrm{A} \beta \mathrm{PP}$ processing to an amyloidogenic derivative $[63,64]$. Cybrid cell lines transplanted with AD subject platelet mitochondria overproduce $\mathrm{A} \beta_{42}$ [65].

These findings are not surprising; the effects of oxidative stress on kinase and $\beta$-secretase activation are well recognized [66,67]. Mitochondria are the single greatest source of cell free radical production [68]. Azide-mediated cytochrome oxidase inhibition increases free radical production [69], and oxygen radical production is increased in AD cybrid cell lines with reduced cytochrome oxidase $\mathrm{V}_{\max }$ activities [24, 70].

The mitochondria- $\mathrm{A} \beta$ nexus is an area of increasing interest among the AD research community [71-75]. After it was established that cytochrome oxidase $\mathrm{V}_{\max }$ activities were reduced in AD subjects, several investigators reported $\mathrm{A} \beta$ inhibits the ETC in general and cytochrome oxidase specifically [76-78]. While these are important studies, they do not adequately explain lower cytochrome oxidase activity in AD platelets, as $\mathrm{A} \beta$ levels are lower in the blood of $\mathrm{AD}$ subjects than they are in the blood of control subjects.

$\mathrm{A} \beta_{42}$ in particular is regarded to be cell-toxic. This is largely based on numerous in vitro studies in which cultured cells were treated with pre-synthesized $\mathrm{A} \beta_{42}$ protein. Numerous attempts to explain the cell toxicity of $\mathrm{A} \beta_{42}$ have been proposed but there is still no single accepted mechanism and it is unclear whether mechanisms identified in in vitro studies apply to human AD. In one study particularly relevant to this discussion, NT2 wild type and NT2 $\rho 0$ cells were exposed to A $\beta_{42}$ protein oligomers [79]. $\mathrm{A} \beta_{42}$ reduced wild type but not $\rho 0$ cell viability. This finding suggests that under in vitro conditions $\mathrm{A} \beta_{42}$ toxicity is mediated through effects on ETC function.

An increasing number of studies report $\mathrm{A} \beta \mathrm{PP}$ and $\mathrm{A} \beta$ associate with mitochondria [80-87]. These proteins have been found in both the mitochondrial inner membrane and in the mitochondrial matrix. These 
studies are not inconsistent with the amyloid cascade hypothesis and potentially reveal how $\mathrm{A} \beta \mathrm{PP}$ mutation or $\mathrm{A} \beta$ species could at least mediate autosomal dominant $\mathrm{AD}$. Whether or not $\mathrm{A} \beta$ species drive or mediate late-onset $\mathrm{AD}$ is less clear. This question is unlikely to be settled without a clear explanation of how and why $\mathrm{A} \beta$ accumulates in the vast majority (over $99 \%$ ) of $\mathrm{AD}$ cases in which A $\beta$ PP and PS mutations are not found.

Fukui and collaborators attempted to address this conundrum using genetically altered mice [88]. AD double transgenic mice expressing $\mathrm{A} \beta \mathrm{PP}$ and PS1 gene mutations were crossed with mice that develop conditional Cre-loxP mediated knock out of neuron COX10. COX10 does not encode a cytochrome oxidase subunit, but rather a farnesyl transferase that synthesizes a cytochrome oxidase heme component. COX10 knock out was intended to mimic the $\mathrm{AD}$ cytochrome oxidase defect, but COX10 knock out induced at least two mitochondrial changes that were opposite to what is observed in AD patient brains. The COX10 knock out mice showed profound reductions in $\mathrm{COX} 1$ protein and oxidative stress, whereas AD brains show profound increases in COX1 protein and oxidative stress [57]. The crossed mice had robust reductions in $\mathrm{A} \beta$ plaque accumulation and $\mathrm{A} \beta_{42}$ protein levels. The authors concluded defects in neuron cytochrome oxidase do not increase oxidative damage and do not promote formation of amyloidgenic $\mathrm{A} \beta \mathrm{PP}$ fragments. While true in this experimental model, we hesitate to extrapolate this interpretation to human AD. The nature of the cytochrome oxidase perturbation in COX10 knock out mice does not seem to model the type of cytochrome oxidase perturbation found in $\mathrm{AD}$ subjects, and given the known correlation between oxidative stress and $\beta$ secretase activity it is not surprising COX10 knock out reduced $\mathrm{A} \beta$ levels. Still, the study elegantly demonstrates mitochondrial function influences $\mathrm{A} \beta \mathrm{PP}$ processing.

Human studies further establish links between $\mathrm{A} \beta$ and neuron metabolism. Unlike the many in vitro studies commonly cited to establish $\mathrm{A} \beta$ neurotoxicity, in these human studies $\mathrm{A} \beta$ does not appear to act as a neurotoxin. On the contrary, neurologic recovery from acute brain injury associates with increased $\mathrm{A} \beta$ production [89]. Interstitial fluid $\mathrm{A} \beta$ levels also vary with sleep-wake cycles; in mice, wakefulness associates with increased interstitial fluid $\mathrm{A} \beta$, and sleep associates with decreased interstitial fluid $\mathrm{A} \beta$ [90].

The debate continues over whether mitochondrial function alters $\mathrm{A} \beta$ dynamics or $\mathrm{A} \beta$ alters mitochondrial function in late-onset AD. Reduced cytochrome oxidase activity and plaque deposition are evident during the MCI phase of AD [91,92], and even before. PIB PET imaging reveals amyloid accumulates in the middle aged children of asymptomatic at least some AD subjects [47]. Because brain mitochondrial function and $\mathrm{A} \beta$ dynamics are potentially entwined, it may be difficult to resolve this question by studying brain. We believe in this case the systemic nature of the AD cytochrome oxidase defect is particularly relevant and informative; the AD cytochrome oxidase defect exists outside the brain in an $\mathrm{A} \beta$-independent fashion. Largely for this reason we suspect mitochondrial function determines amyloidosis in late-onset AD.

\section{RELATIVE STRENGTHS OF THE MITOCHONDRIAL CASCADE HYPOTHESIS}

\section{Aging}

Both late-onset $\mathrm{AD}$ prevalence and incidence rise sharply with advancing age [30-32,93]. In developing our hypothesis, we have therefore considered aging theory and how it may relate to late-onset $\operatorname{AD}[15,16]$. We have intentionally incorporated aging theory into our core principles.

An association between advancing age and declining mitochondrial function has long been noted [37]. Whether declining mitochondrial function is a cause or consequence of aging is an important question. Investigators have tried to address this by using genetically altered mice with defective mtDNA polymerase $\gamma$ proofreading ability $[37,38,50]$. These mice accumulate somatic mtDNA mutations at accelerated rates and show accelerated aging. This suggests declining mitochondrial function can drive an aging phenotype.

Genetic association studies report mtDNA polymorphisms and haplogroups influence longevity; mtDNA haplogroups may also influence AD risk [94,95]. One large epidemiology study found that while maternal and paternal longevity both influence an individual's life expectancy, maternal longevity has a greater impact [96, 97]. This pattern is similar to what was observed in the AD endophenotype studies discussed above. Overall, a maternally inherited genetic factor appears to influence both life expectancy and AD risk.

\section{APOE/TOMM40}

Although late-onset AD is considered a sporadic or pseudo-sporadic disorder, it is clear that AD risk is genetically influenced. In 1991 an association between 
$\mathrm{AD}$ and the proximal long arm of chromosome 19 was revealed [98]. Polymorphisms in the $A P O E$ gene are believed to mediate this association but the physiologic basis of this relationship remains uncertain [99]. Different studies report different potential mechanisms. Apolipoprotein E protein has been shown to influence $\mathrm{A} \beta$ trafficking and cell signal transduction, either of which could affect A $\beta$ toxicity $[100,101]$. Apolipoprotein $\mathrm{E}$ or its degradation products also appear to influence mitochondrial function [102].

It now appears polymorphisms in a neighboring gene, TOMM40, associate with AD risk [103-105]. This association may arise via effects on $A P O E$ expression, or may exist independent of APOE [106-108]. TOMM40 encodes a translocase of the outer mitochondrial membrane protein. It would be interesting to know how much late-onset AD risk is specifically determined by $A P O E$ alleles and how much is specifically determined by TOMM40 alleles, as well as what degree of association is determined by effects on mitochondrial function.

\section{Systemic manifestations}

Weight loss manifests early in $\mathrm{AD}$ and during the lead-up to it [109-118]. We extended this finding by showing body composition and cognitive decline rates correlate; MCI subjects with low body mass index (BMI) values progress more rapidly than those with high BMI values [119]. We also found AD subjects have reduced lean (muscle) mass and bone density [120-122]. These changes correlate quantitatively with brain atrophy and cognitive dysfunction.

We determined peak oxygen consumption $\left(\mathrm{VO}_{2}^{\text {peak }}\right)$ in an $\mathrm{AD}$ subject cohort [123]. $\mathrm{VO}_{2}^{\text {peak }}$ represents the peak rate of metabolic activity (oxygen utilization) in exercising muscle. Compared to control subjects, AD subjects had reduced $\mathrm{VO}_{2}^{\text {peak }}$ values. This correlates with brain atrophy and is not due to differences in cognitive function or baseline physical activity [124,125]. $\mathrm{VO}_{2}^{\text {peak }}$ reduction suggests muscle aerobic capacity is fundamentally altered in $\mathrm{AD}$.

Accumulating evidence suggests insulin signaling is altered in AD [126]. AD patients tend towards higher peripheral but lower central insulin levels [127]. We examined relationships between peripheral insulin, cognitive function, and brain volume in non-diabetic AD subjects [128]. As a group, individuals with higher serum insulin levels had less brain atrophy and better cognitive performance. The reasons for this are unclear. Our findings suggest insulin either has a disease modifying effect or else represents a sensitive biomarker of peripheral disease severity. We suspect the latter possibility is more likely.

It is increasingly apparent that AD-affected individuals have altered insulin levels, muscle mass, bone density, and peak oxygen consumption. These metabolismrelevant changes correlate with brain atrophy, correlate with cognitive performance, and are observed during the disease's earliest detectable clinical stages. We predict systemic mitochondrial perturbations are at least partly responsible.

\section{THERAPEUTIC IMPLICATIONS}

The mitochondrial cascade hypothesis proposes declining mitochondrial function activates downstream cellular changes observed in late-onset AD. This includes $\mathrm{A} \beta$ amyloidosis, tau phosphorylation, oxidative stress, synaptic loss, and neurodegeneration. We believe therapeutic development efforts should target declining mitochondrial function.

Our hypothesis predicts therapies that enhance neuron aerobic metabolism may benefit late-onset AD patients $[129,130]$. Various approaches may accomplish this; some are technically simple and others far more complex. One simple approach includes the delivery of ketone bodies to the brain. We first proposed the use of betahydroxybutyrate for the treatment of $\mathrm{AD}$ in 1989 [131]. Our idea was based on studies of AD rapid autopsy brains. We demonstrated homogenates prepared from these brains consume betahydroxybutyrate. Betahydroxybutyrate feeds acetyl units directly into the Krebs cycle, which in theory could enhance aerobic metabolism by providing ETC reducing equivalents. Almost two decades later, a clinical study reported that increasing serum betahydroxybutyrate levels may benefit cognition in some AD patients [132].

We and others previously proposed using brain mitochondrial biogenesis induction to treat AD [133,134]. Efforts to date have been hindered by an incomplete understanding of the mechanisms that mediate brain mitochondrial biogenesis, as well as a dearth of compounds that induce brain mitochondrial biogenesis at brain-achievable concentrations $[133,135]$. We have also proposed the enhancement of mitochondrial gene expression to treat AD [136]. To this end we are developing a chimeric recombinant human transcription factor A (rhTFAM) protein that can transduce cell plasma and mitochondrial membranes, bind mtDNA, and activate both mtDNA expression and replication [137]. 
The mitochondrial cascade hypothesis also predicts certain extensively considered therapeutic interventions may provide either no or very limited clinical benefit. Our theory predicts free radical scavengers will not prove particularly efficacious because in our scheme increased free radical production is a consequence and not a cause of declining aerobic metabolism. Antioxidants may help to a limited extent if it turns out increased mitochondrial free radical production forms part of a feedback loop that further reduces mitochondrial respiration, but according to our hypothesis this would not repair the primary problem and could possibly mitigate compensation-oriented stress signaling pathways.

Similarly, the mitochondrial cascade hypothesis sees $\mathrm{A} \beta$ accumulation as a downstream event and addressing $\mathrm{A} \beta$ accumulation by blocking production, enhancing removal, or preventing oligomerization should have limited effects $[15,16]$. Such interventions could perhaps help to some degree if $\mathrm{A} \beta$ does in fact form part of a feedback loop that reduces mitochondrial respiration in already failing mitochondria. Eliminating $\mathrm{A} \beta$ would not correct the primary problem, though, and would not be expected to dramatically alter clinical progression. Results from several recent anti-amyloid clinical trials are consistent with this view [138-142]. Because our hypothesis assumes sporadic, late-onset AD and autosomal dominant AD do not share a common etiology, disappointing results from late-onset $\mathrm{AD}$ trials may not extrapolate to autosomal dominant AD. It is still possible anti-amyloid strategies could have a profound effect in persons with autosomal dominant $\mathrm{AD}$.

\section{CONCLUSIONS}

The idea that mitochondria play an important role in $\mathrm{AD}$ is not nearly as heretical as it once was. A recent high-profile AD review article surveying the contemporary understanding of AD pathogenesis acknowledged mitochondria are probably relevant to this disease [143].

We first proposed the mitochondrial cascade hypothesis in 2004 [15,16]. Our hypothesis assumed mitochondria initiate late-onset AD pathologies. Since then data consistent with our core assertions have been published. Our hypothesis is especially strong on several accounts. It reconciles AD research with brain aging research, provides insight into late-onset $\mathrm{AD}$ epidemiology and endophenotype studies, and explains biochemical and physiologic changes that occur outside the brain in AD. Right or wrong, we feel our hypothesis provides a unique perspective that will hopefully contribute to advances in the AD research field.

\section{ACKNOWLEDGMENTS}

This work was supported by the National Institutes of Health (AG022407 to R.H.S.; AG026374, AG029615, and K23NS058252 to J.M.B.; and EY018474 to S.M.K.). Clinical research performed in our studies was facilitated by the University of Kansas General Clinical Research Center (M01RR023940).

Authors' disclosures available online (http://www.jalz.com/disclosures/view.php?id=402).

\section{REFERENCES}

[1] Hardy JA, Higgins GA (1992) Alzheimer's disease: the amyloid cascade hypothesis. Science 256, 184-185.

[2] Hardy J, Selkoe DJ (2002) The amyloid hypothesis of Alzheimer's disease: progress and problems on the road to therapeutics. Science 297, 353-356.

[3] Walsh DM, Selkoe DJ (2007) A beta oligomers - a decade of discovery. J Neurochem 101, 1172-1184.

[4] Goate A, Chartier-Harlin MC, Mullan M, Brown J, Crawford F, Fidani L, Giuffra L, Haynes A, Irving N, James L, et al. (1991) Segregation of a missense mutation in the amyloid precursor protein gene with familial Alzheimer's disease. Nature 349, 704-706.

[5] Sherrington R, Rogaev EI, Liang Y, Rogaeva EA, Levesque G, Ikeda M, Chi H, Lin C, Li G, Holman K, et al. (1995) Cloning of a gene bearing missense mutations in early-onset familial Alzheimer's disease. Nature 375, 754-760.

[6] Levy-Lahad E, Wasco W, Poorkaj P, Romano DM, Oshima J, Pettingell WH, Yu CE, Jondro PD, Schmidt SD, Wang K, et al. (1995) Candidate gene for the chromosome 1 familial Alzheimer's disease locus. Science 269, 973-977.

[7] Wolfe MS, Xia W, Ostaszewski BL, Diehl TS, Kimberly WT, Selkoe DJ (1999) Two transmembrane aspartates in presenilin-1 required for presenilin endoproteolysis and gamma-secretase activity. Nature 398, 513-517.

[8] Kimberly WT, Xia W, Rahmati T, Wolfe MS, Selkoe DJ (2000) The transmembrane aspartates in presenilin 1 and 2 are obligatory for gamma-secretase activity and amyloid beta-protein generation. J Biol Chem 275, 3173-3178.

[9] Scheuner D, Eckman C, Jensen M, Song X, Citron M, Suzuki N, Bird TD, Hardy J, Hutton M, Kukull W, Larson E, LevyLahad E, Viitanen M, Peskind E, Poorkaj P, Schellenberg G, Tanzi R, Wasco W, Lannfelt L, Selkoe D, Younkin S (1996) Secreted amyloid beta-protein similar to that in the senile plaques of Alzheimer's disease is increased in vivo by the presenilin 1 and 2 and APP mutations linked to familial Alzheimer's disease. Nat Med 2, 864-870.

[10] Swerdlow RH (2007) Pathogenesis of Alzheimer's disease. Clin Interv Aging 2, 347-359.

[11] Brown P, Salazar AM, Gibbs CJ, Jr., Gajdusek DC (1982) Alzheimer's disease and transmissible virus dementia (Creutzfeldt-Jakob disease). Ann N Y Acad Sci 396, 131-143.

[12] Toledano-Gasca A (1988) Hypotheses concerning the aetiology of Alzheimer's disease. Pharmacopsychiatry 21(Suppl 1), 17-25.

[13] Trojanowski JQ (2002) Tauists, Baptists, Syners, Apostates, and new data. Ann Neurol 52, 263-265. 
[14] Zhu X, Raina AK, Perry G, Smith MA (2004) Alzheimer's disease: the two-hit hypothesis. Lancet Neurol 3, 219-226.

[15] Swerdlow RH, Khan SM (2004) A "mitochondrial cascade hypothesis" for sporadic Alzheimer's disease. Med Hypotheses 63, 8-20.

[16] Swerdlow RH, Khan SM (2009) The Alzheimer's disease mitochondrial cascade hypothesis: an update. Exp Neurol 218, 308-315.

[17] Perry EK, Perry RH, Tomlinson BE, Blessed G, Gibson PH (1980) Coenzyme A-acetylating enzymes in Alzheimer's disease: possible cholinergic 'compartment' of pyruvate dehydrogenase. Neurosci Lett 18, 105-110.

[18] Sorbi S, Bird ED, Blass JP (1983) Decreased pyruvate dehydrogenase complex activity in Huntington and Alzheimer brain. Ann Neurol 13, 72-78.

[19] Gibson GE, Sheu KF, Blass JP, Baker A, Carlson KC, Harding B, Perrino P (1988) Reduced activities of thiaminedependent enzymes in the brains and peripheral tissues of patients with Alzheimer's disease. Arch Neurol 45, 836-840.

[20] Parker WD, Jr., Filley CM, Parks JK (1990) Cytochrome oxidase deficiency in Alzheimer's disease. Neurology 40 1302-1303.

[21] Kish SJ, Bergeron C, Rajput A, Dozic S, Mastrogiacomo F, Chang LJ, Wilson JM, DiStefano LM, Nobrega JN (1992) Brain cytochrome oxidase in Alzheimer's disease. $\mathrm{J} \mathrm{Neu}$ rochem 59, 776-779.

[22] Swerdlow RH, Kish SJ (2002) Mitochondria in Alzheimer's disease. Int Rev Neurobiol 53, 341-385.

[23] King MP, Attardi G (1989) Human cells lacking mtDNA: repopulation with exogenous mitochondria by complementation. Science 246, 500-503.

[24] Swerdlow RH, Parks JK, Cassarino DS, Maguire DJ, Maguire RS, Bennett JP, Jr., Davis RE, Parker WD, Jr. (1997) Cybrids in Alzheimer's disease: a cellular model of the disease? Neurology 49, 918-925.

[25] Sheehan JP, Swerdlow RH, Miller SW, Davis RE, Parks JK, Parker WD, Tuttle JB (1997) Calcium homeostasis and reactive oxygen species production in cells transformed by mitochondria from individuals with sporadic Alzheimer's disease. J Neurosci 17, 4612-4622.

[26] Swerdlow RH (2007) Mitochondria in cybrids containing mtDNA from persons with mitochondriopathies. J Neurosci Res 85, 3416-3428.

[27] Xia W, Yang T, Shankar G, Smith IM, Shen Y, Walsh DM Selkoe DJ (2009) A specific enzyme-linked immunosorbent assay for measuring beta-amyloid protein oligomers in human plasma and brain tissue of patients with Alzheimer disease. Arch Neurol 66, 190-199.

[28] Swerdlow RH (2007) Is aging part of Alzheimer's disease, or is Alzheimer's disease part of aging? Neurobiol Aging 28, 1465-1480.

[29] Nunes T, Fragata I, Ribeiro F, Palma T, Maroco J, Cannas J, Secca M, Menezes C, Carmo I, Cunha G, Branco MC, Guerreiro M, de Mendonca A (2010) The outcome of elderly patients with cognitive complaints but normal neuropsychological tests. J Alzheimers Dis 19, 137-145.

[30] Jorm AF, Jolley D (1998) The incidence of dementia: a meta-analysis. Neurology 51, 728-733.

[31] Corrada MM, Brookmeyer R, Berlau D, Paganini-Hill A, Kawas CH (2008) Prevalence of dementia after age 90: results from the 90+ study. Neurology 71, 337-343.

[32] Hogan DB (2008) If we live long enough, will we all be demented?: redux. Neurology 71, 310-311.

[33] Katzman R (1976) Editorial: The prevalence and malignancy of Alzheimer disease. A major killer. Arch Neurol 33, 217 218.

[34] Savva GM, Wharton SB, Ince PG, Forster G, Matthews FE, Brayne C (2009) Age, neuropathology, and dementia. NEngl J Med 360, 2302-2309.

[35] Price JL, Morris JC (1999) Tangles and plaques in nondemented aging and "preclinical" Alzheimer's disease. Ann Neurol 45, 358-368.

[36] Morris JC, Roe CM, Grant EA, Head D, Storandt M, Goate AM, Fagan AM, Holtzman DM, Mintun MA (2009) Pittsburgh compound $\mathrm{B}$ imaging and prediction of progression from cognitive normality to symptomatic Alzheimer disease. Arch Neurol 66, 1469-1475.

[37] Navarro A, Boveris A (2007) The mitochondrial energy transduction system and the aging process. Am J Physiol Cell Physiol 292, C670-686.

[38] Trifunovic A, Wredenberg A, Falkenberg M, Spelbrink JN, Rovio AT, Bruder CE, Bohlooly YM, Gidlof S, Oldfors A, Wibom R, Tornell J, Jacobs HT, Larsson NG (2004) Premature ageing in mice expressing defective mitochondrial DNA polymerase. Nature 429, 417-423.

[39] Katzman R (1986) Alzheimer's disease. N Engl J Med 314 , 964-973.

[40] Edland SD, Silverman JM, Peskind ER, Tsuang D, Wijsman E, Morris JC (1996) Increased risk of dementia in mothers of Alzheimer's disease cases: evidence for maternal inheritance. Neurology 47, 254-256.

[41] Duara R, Lopez-Alberola RF, Barker WW, Loewenstein DA, Zatinsky M, Eisdorfer CE, Weinberg GB (1993) A comparison of familial and sporadic Alzheimer's disease. Neurology 43, 1377-1384.

[42] Silverman DH, Small GW, Chang CY, Lu CS, Kung De Aburto MA, Chen W, Czernin J, Rapoport SI, Pietrini P, Alexander GE, Schapiro MB, Jagust WJ, Hoffman JM, Welsh-Bohmer KA, Alavi A, Clark CM, Salmon E, de Leon MJ, Mielke R, Cummings JL, Kowell AP, Gambhir SS, Hoh CK, Phelps ME (2001) Positron emission tomography in evaluation of dementia: Regional brain metabolism and long-term outcome. JAMA 286, 2120-2127.

[43] Mosconi L, Brys M, Switalski R, Mistur R, Glodzik L, Pirraglia E, Tsui W, De Santi S, de Leon MJ (2007) Maternal family history of Alzheimer's disease predisposes to reduced brain glucose metabolism. Proc Natl Acad Sci U S A 104, 19067-19072.

[44] Mosconi L, Mistur R, Switalski R, Brys M, Glodzik L, Rich K, Pirraglia E, Tsui W, De Santi S, de Leon MJ (2009) Declining brain glucose metabolism in normal individuals with a maternal history of Alzheimer disease. Neurology 72, 513-520.

[45] Honea RA, Swerdlow RH, Vidoni ED, Goodwin J, Burns JM (2010) Reduced gray matter volume in normal adults with a maternal family history of Alzheimer disease. Neurology 74, 113-120.

[46] Johnson KA (2006) Amyloid imaging of Alzheimer's disease using Pittsburgh Compound B. Curr Neurol Neurosci Rep 6, 496-503.

[47] Mosconi L, Rinne JO, Tsui WH, Berti V, Li Y, Wang H, Murray J, Scheinin N, MNagren K, Glodzik L, De Santi S, Vallabhajosula S, de Leon MJ (2010) Increased fibrillar amyloid-beta burden in normal individuals with a family history of late-onset Alzheimer's. Proc Natl Acad Sci U S A 107, 5949-5954.

[48] Debette S, Wolf PA, Beiser A, Au R, Himali JJ, Pikula A, Auerbach S, Decarli C, Seshadri S (2009) Association of 
parental dementia with cognitive and brain MRI measures in middle-aged adults. Neurology 73, 2071-2078.

[49] Lu J, Wang KX, Rodova M, Esteves R, Berry D, E L, Crafter A, Barrett M, Cardoso SM, Onyango I, Parker WD, Fontes J, Burns JM, Swerdlow RH (2010) Polymorphic variation in cytochrome oxidase subunit genes. J Alzheimers Dis, in press.

[50] Kujoth GC, Hiona A, Pugh TD, Someya S, Panzer K, Wohlgemuth SE, Hofer T, Seo AY, Sullivan R, Jobling WA, Morrow JD, Van Remmen H, Sedivy JM, Yamasoba T, Tanokura M, Weindruch R, Leeuwenburgh C, Prolla TA (2005) Mitochondrial DNA mutations, oxidative stress, and apoptosis in mammalian aging. Science 309, 481-484.

[51] Lin MT, Simon DK, Ahn CH, Kim LM, Beal MF (2002) High aggregate burden of somatic mtDNA point mutations in aging and Alzheimer's disease brain. Hum Mol Genet 11, 133-145.

[52] Coskun PE, Beal MF, Wallace DC (2004) Alzheimer's brains harbor somatic mtDNA control-region mutations that suppress mitochondrial transcription and replication. Proc Natl Acad Sci U S A 101, 10726-10731.

[53] Corral-Debrinski M, Horton T, Lott MT, Shoffner JM, McKee AC, Beal MF, Graham BH, Wallace DC (1994) Marked changes in mitochondrial DNA deletion levels in Alzheimer brains. Genomics 23, 471-476.

[54] Hamblet NS, Castora FJ (1997) Elevated levels of the KearnsSayre syndrome mitochondrial DNA deletion in temporal cortex of Alzheimer's patients. Mutat Res 379, 253-262.

[55] Bender A, Krishnan KJ, Morris CM, Taylor GA, Reeve AK, Perry RH, Jaros E, Hersheson JS, Betts J, Klopstock T, Taylor RW, Turnbull DM (2006) High levels of mitochondrial DNA deletions in substantia nigra neurons in aging and Parkinson disease. Nat Genet 38, 515-517.

[56] Kraytsberg Y, Kudryavtseva E, McKee AC, Geula C, Kowall NW, Khrapko K (2006) Mitochondrial DNA deletions are abundant and cause functional impairment in aged human substantia nigra neurons. Nat Genet 38, 518-520.

[57] Hirai K, Aliev G, Nunomura A, Fujioka H, Russell RL, Atwood CS, Johnson AB, Kress Y, Vinters HV, Tabaton M, Shimohama S, Cash AD, Siedlak SL, Harris PL, Jones PK, Petersen RB, Perry G, Smith MA (2001) Mitochondrial abnormalities in Alzheimer's disease. J Neurosci 21, 3017-3023.

[58] de la Monte SM, Luong T, Neely TR, Robinson D, Wands JR (2000) Mitochondrial DNA damage as a mechanism of cell loss in Alzheimer's disease. Lab Invest 80, 1323-1335.

[59] Brown AM, Sheu RK, Mohs R, Haroutunian V, Blass JP (2001) Correlation of the clinical severity of Alzheimer's disease with an aberration in mitochondrial DNA (mtDNA). J Mol Neurosci 16, 41-48.

[60] Szabados T, Dul C, Majtenyi K, Hargitai J, Penzes Z, Urbanics R (2004) A chronic Alzheimer's model evoked by mitochondrial poison sodium azide for pharmacological investigations. Behav Brain Res 154, 31-40.

[61] Escobar-Khondiker M, Hollerhage M, Muriel MP, Champy P, Bach A, Depienne C, Respondek G, Yamada ES, Lannuzel A, Yagi T, Hirsch EC, Oertel WH, Jacob R, Michel PP, Ruberg M, Hoglinger GU (2007) Annonacin, a natural mitochondrial complex I inhibitor, causes tau pathology in cultured neurons. J Neurosci 27, 7827-7837.

[62] Hoglinger GU, Lannuzel A, Khondiker ME, Michel PP, Duyckaerts C, Feger J, Champy P, Prigent A, Medja F, Lombes A, Oertel WH, Ruberg M, Hirsch EC (2005) The mitochondrial complex I inhibitor rotenone triggers a cerebral tauopathy. $J$ Neurochem 95, 930-939.
[63] Gabuzda D, Busciglio J, Chen LB, Matsudaira P, Yankner BA (1994) Inhibition of energy metabolism alters the processing of amyloid precursor protein and induces a potentially amyloidogenic derivative. J Biol Chem 269, 13623-13628.

[64] Gasparini L, Racchi M, Benussi L, Curti D, Binetti G, Bianchetti A, Trabucchi M, Govoni S (1997) Effect of energy shortage and oxidative stress on amyloid precursor protein metabolism in COS cells. Neurosci Lett 231, 113-117.

[65] Khan SM, Cassarino DS, Abramova NN, Keeney PM, Borland MK, Trimmer PA, Krebs CT, Bennett JC, Parks JK, Swerdlow RH, Parker WD, Jr., Bennett JP, Jr. (2000) Alzheimer's disease cybrids replicate beta-amyloid abnormalities through cell death pathways. Ann Neurol 48, 148155.

[66] Tamagno E, Bardini P, Obbili A, Vitali A, Borghi R, Zaccheo D, Pronzato MA, Danni O, Smith MA, Perry G, Tabaton M (2002) Oxidative stress increases expression and activity of BACE in NT2 neurons. Neurobiol Dis 10, 279-288.

[67] Clerk A, Fuller SJ, Michael A, Sugden PH (1998) Stimulation of "stress-regulated" mitogen-activated protein kinases (stress-activated protein kinases/c-Jun N-terminal kinases and p38-mitogen-activated protein kinases) in perfused rat hearts by oxidative and other stresses. J Biol Chem 273, 7228-7234.

[68] Shigenaga MK, Hagen TM, Ames BN (1994) Oxidative damage and mitochondrial decay in aging. Proc Natl Acad Sci U $S$ A 91, 10771-10778.

[69] Barrett MJ, Alones V, Wang KX, Phan L, Swerdlow RH (2004) Mitochondria-derived oxidative stress induces a heat shock protein response. J Neurosci Res 78, 420-429.

[70] Cardoso SM, Santana I, Swerdlow RH, Oliveira CR (2004) Mitochondria dysfunction of Alzheimer's disease cybrids enhances Abeta toxicity. J Neurochem 89, 1417-1426.

[71] Wang X, Su B, Fujioka H, Zhu X (2008) Dynamin-like protein 1 reduction underlies mitochondrial morphology and distribution abnormalities in fibroblasts from sporadic Alzheimer's disease patients. Am J Pathol 173, 470-482.

[72] Wang X, Su B, Lee HG, Li X, Perry G, Smith MA, Zhu X (2009) Impaired balance of mitochondrial fission and fusion in Alzheimer's disease. J Neurosci 29, 9090-9103.

[73] Wang X, Su B, Siedlak SL, Moreira PI, Fujioka H, Wang Y, Casadesus G, Zhu X (2008) Amyloid-beta overproduction causes abnormal mitochondrial dynamics via differential modulation of mitochondrial fission/fusion proteins. Proc Natl Acad Sci U S A 105, 19318-19323.

[74] Zhao XL, Wang WA, Tan JX, Huang JK, Zhang X, Zhang BZ, Wang YH, YangCheng HY, Zhu HL, Sun XJ, Huang FD (2010) Expression of beta-amyloid Induced age-dependent presynaptic and axonal changes in Drosophila. J Neurosci 30, 1512-1522.

[75] Du H, Guo L, Fang F, Chen D, Sosunov AA, McKhann GM, Yan Y, Wang C, Zhang H, Molkentin JD, Gunn-Moore FJ, Vonsattel JP, Arancio O, Chen JX, Yan SD (2008) Cyclophilin $\mathrm{D}$ deficiency attenuates mitochondrial and neuronal perturbation and ameliorates learning and memory in Alzheimer's disease. Nat Med 14, 1097-1105.

[76] Pereira C, Santos MS, Oliveira C (1998) Mitochondrial function impairment induced by amyloid beta-peptide on PC12 cells. Neuroreport 9, 1749-1755.

[77] Canevari L, Clark JB, Bates TE (1999) beta-Amyloid fragment 25-35 selectively decreases complex IV activity in isolated mitochondria. FEBS Lett 457, 131-134.

[78] Crouch PJ, Blake R, Duce JA, Ciccotosto GD, Li QX, Barnham KJ, Curtain CC, Cherny RA, Cappai R, Dyrks T, Mas- 
ters CL, Trounce IA (2005) Copper-dependent inhibition of human cytochrome $\mathrm{c}$ oxidase by a dimeric conformer of amyloid-beta1-42. J Neurosci 25, 672-679.

[79] Cardoso SM, Santos S, Swerdlow RH, Oliveira CR (2001) Functional mitochondria are required for amyloid betamediated neurotoxicity. FASEB J 15, 1439-1441.

[80] Yamaguchi H, Yamazaki T, Ishiguro K, Shoji M, Nakazato Y, Hirai S (1992) Ultrastructural localization of Alzheimer amyloid beta/A4 protein precursor in the cytoplasm of neurons and senile plaque-associated astrocytes. Acta Neuropathol 85, 15-22.

[81] Anandatheerthavarada HK, Biswas G, Robin MA, Avadhani NG (2003) Mitochondrial targeting and a novel transmembrane arrest of Alzheimer's amyloid precursor protein impairs mitochondrial function in neuronal cells. J Cell Biol 161, 41-54.

[82] Caspersen C, Wang N, Yao J, Sosunov A, Chen X, Lustbader JW, Xu HW, Stern D, McKhann G, Yan SD (2005) Mitochondrial Abeta: a potential focal point for neuronal metabolic dysfunction in Alzheimer's disease. FASEB J 19, 2040-2041.

[83] Hansson Petersen CA, Alikhani N, Behbahani H, Wiehager B, Pavlov PF, Alafuzoff I, Leinonen V, Ito A, Winblad B, Glaser E, Ankarcrona M (2008) The amyloid beta-peptide is imported into mitochondria via the TOM import machinery and localized to mitochondrial cristae. Proc Natl Acad Sci U $S$ A 105, 13145-13150.

[84] Lustbader JW, Cirilli M, Lin C, Xu HW, Takuma K, Wang N, Caspersen C, Chen X, Pollak S, Chaney M, Trinchese F, Liu S, Gunn-Moore F, Lue LF, Walker DG, Kuppusamy P, Zewier ZL, Arancio O, Stern D, Yan SS, Wu H (2004) ABAD directly links Abeta to mitochondrial toxicity in Alzheimer's disease. Science 304, 448-452.

[85] Anandatheerthavarada HK, Devi L (2007) Amyloid precursor protein and mitochondrial dysfunction in Alzheimer's disease. Neuroscientist 13, 626-638.

[86] Devi L, Prabhu BM, Galati DF, Avadhani NG, Anandatheerthavarada HK (2006) Accumulation of amyloid precursor protein in the mitochondrial import channels of human Alzheimer's disease brain is associated with mitochondrial dysfunction. J Neurosci 26, 9057-9068.

[87] Manczak M, Anekonda TS, Henson E, Park BS, Quinn J, Reddy PH (2006) Mitochondria are a direct site of A beta accumulation in Alzheimer's disease neurons: implications for free radical generation and oxidative damage in disease progression. Hum Mol Genet 15, 1437-1449.

[88] Fukui H, Diaz F, Garcia S, Moraes CT (2007) Cytochrome c oxidase deficiency in neurons decreases both oxidative stress and amyloid formation in a mouse model of Alzheimer's disease. Proc Natl Acad Sci U S A 104, 14163-14168.

[89] Brody DL, Magnoni S, Schwetye KE, Spinner ML, Esparza TJ, Stocchetti N, Zipfel GJ, Holtzman DM (2008) Amyloidbeta dynamics correlate with neurological status in the injured human brain. Science 321, 1221-1224.

[90] Kang JE, Lim MM, Bateman RJ, Lee JJ, Smyth LP, Cirrito JR, Fujiki N, Nishino S, Holtzman DM (2009) Amyloid-beta dynamics are regulated by orexin and the sleep-wake cycle. Science 326, 1005-1007.

[91] Valla J, Schneider L, Niedzielko T, Coon KD, Caselli R, Sabbagh MN, Ahern GL, Baxter L, Alexander G, Walker DG, Reiman EM (2006) Impaired platelet mitochondrial activity in Alzheimer's disease and mild cognitive impairment. Mitochondrion 6, 323-330.

[92] Kemppainen NM, Aalto S, Wilson IA, Nagren K, Helin S, Bruck A, Oikonen V, Kailajarvi M, Scheinin M, Viitanen M,
Parkkola R, Rinne JO (2007) PET amyloid ligand [11C] PIB uptake is increased in mild cognitive impairment. Neurology 68, 1603-1606.

[93] Evans DA, Funkenstein HH, Albert MS, Scherr PA, Cook NR, Chown MJ, Hebert LE, Hennekens CH, Taylor JO (1989) Prevalence of Alzheimer's disease in a community population of older persons. Higher than previously reported. JAMA 262, 2551-2556.

[94] De Benedictis G, Rose G, Carrieri G, De Luca M, Falcone E, Passarino G, Bonafe M, Monti D, Baggio G, Bertolini S, Mari D, Mattace R, Franceschi C (1999) Mitochondrial DNA inherited variants are associated with successful aging and longevity in humans. FASEB J 13, 1532-1536.

[95] van der Walt JM, Dementieva YA, Martin ER, Scott WK, Nicodemus KK, Kroner CC, Welsh-Bohmer KA, Saunders AM, Roses AD, Small GW, Schmechel DE, Murali Doraiswamy P, Gilbert JR, Haines JL, Vance JM, Pericak-Vance MA (2004) Analysis of European mitochondrial haplogroups with Alzheimer disease risk. Neurosci Lett 365, 28-32.

[96] Goldberg RJ, Larson M, Levy D (1996) Factors associated with survival to 75 years of age in middle-aged men and women. The Framingham Study. Arch Intern Med 156, 505509.

[97] Brand FN, Kiely DK, Kannel WB, Myers RH (1992) Family patterns of coronary heart disease mortality: the Framingham Longevity Study. J Clin Epidemiol 45, 169-174.

[98] Pericak-Vance MA, Bebout JL, Gaskell PC, Jr., Yamaoka LH, Hung WY, Alberts MJ, Walker AP, Bartlett RJ, Haynes CA, Welsh KA, et al. (1991) Linkage studies in familial Alzheimer disease: evidence for chromosome 19 linkage. Am J Hum Genet 48, 1034-1050.

[99] Corder EH, Saunders AM, Strittmatter WJ, Schmechel DE, Gaskell PC, Small GW, Roses AD, Haines JL, Pericak-Vance MA (1993) Gene dose of apolipoprotein E type 4 allele and the risk of Alzheimer's disease in late onset families. Science 261, 921-923.

[100] Gandy S, Petanceska S (2001) Regulation of alzheimer betaamyloid precursor trafficking and metabolism. Adv Exp Med Biol 487, 85-100.

[101] Strittmatter WJ (2001) Apolipoprotein E and Alzheimer's disease: signal transduction mechanisms. Biochem Soc Symp, 101-109.

[102] Chang S, ran Ma T, Miranda RD, Balestra ME, Mahley RW, Huang Y (2005) Lipid- and receptor-binding regions of apolipoprotein E4 fragments act in concert to cause mitochondrial dysfunction and neurotoxicity. Proc Natl Acad Sci U S A 102, 18694-18699.

[103] Yu CE, Seltman H, Peskind ER, Galloway N, Zhou PX, Rosenthal E, Wijsman EM, Tsuang DW, Devlin B, Schellenberg GD (2007) Comprehensive analysis of APOE and selected proximate markers for late-onset Alzheimer's disease: patterns of linkage disequilibrium and disease/marker association. Genomics 89, 655-665.

[104] Potkin SG, Guffanti G, Lakatos A, Turner JA, Kruggel F, Fallon JH, Saykin AJ, Orro A, Lupoli S, Salvi E, Weiner M, Macciardi F (2009) Hippocampal atrophy as a quantitative trait in a genome-wide association study identifying novel susceptibility genes for Alzheimer's disease. PLoS One 4, e6501.

[105] Roses AD, Lutz MW, Amrine-Madsen H, Saunders AM, Crenshaw DG, Sundseth SS, Huentelman MJ, WelshBohmer KA, Reiman EM (2009) A TOMM40 variablelength polymorphism predicts the age of late-onset Alzheimer's disease. Pharmacogenomics J, in press. 
[106] Takei N, Miyashita A, Tsukie T, Arai H, Asada T, Imagawa M, Shoji M, Higuchi S, Urakami K, Kimura H, Kakita A, Takahashi H, Tsuji S, Kanazawa I, Ihara Y, Odani S, Kuwano R (2009) Genetic association study on in and around the APOE in late-onset Alzheimer disease in Japanese. Genomics 93, 441-448.

[107] Bekris LM, Galloway NM, Montine TJ, Schellenberg GD, Yu CE (2009) APOE mRNA and protein expression in postmortem brain are modulated by an extended haplotype structure. Am J Med Genet B Neuropsychiatr Genet 153B, 409417.

[108] Bekris LM, Millard SP, Galloway NM, Vuletic S, Albers JJ, Li G, Galasko DR, DeCarli C, Farlow MR, Clark CM, Quinn JF, Kaye JA, Schellenberg GD, Tsuang D, Peskind ER, Yu CE (2008) Multiple SNPs within and surrounding the apolipoprotein $\mathrm{E}$ gene influence cerebrospinal fluid apolipoprotein E protein levels. J Alzheimers Dis 13, 255266.

[109] Johnson DK, Wilkins CH, Morris JC (2006) Accelerated weight loss may precede diagnosis in Alzheimer disease. Arch Neurol 63, 1312-1317.

[110] Buchman AS, Wilson RS, Bienias JL, Shah RC, Evans DA, Bennett DA (2005) Change in body mass index and risk of incident Alzheimer disease. Neurology 65, 892-897.

[111] Stewart R, Masaki K, Xue QL, Peila R, Petrovitch H, White LR, Launer LJ (2005) A 32-year prospective study of change in body weight and incident dementia: the Honolulu-Asia Aging Study. Arch Neurol 62, 55-60.

[112] Barrett-Connor E, Edelstein SL, Corey-Bloom J, Wiederholt WC (1996) Weight loss precedes dementia in communitydwelling older adults. J Am Geriatr Soc 44, 1147-1152.

[113] White H, Pieper C, Schmader K, Fillenbaum G (1996) Weight change in Alzheimer's disease. J Am Geriatr Soc 44, 265272.

[114] Knopman DS, Edland SD, Cha RH, Petersen RC, Rocca WA (2007) Incident dementia in women is preceded by weight loss by at least a decade. Neurology 69, 739-746.

[115] Johnson DK, Wilkins CH, Morris JC (2006) Accelerated Weight Loss May Precede Diagnosis in Alzheimer Disease. Arch Neurol 63, 1312-1317.

[116] Stewart R, Masaki K, Xue QL, Peila R, Petrovitch H, White LR, Launer LJ (2005) A 32-Year Prospective Study of Change in Body Weight and Incident Dementia: The Honolulu-Asia Aging Study. Arch Neurol 62, 55-60.

[117] BarrettConnor E, Edelstein SL, CoreyBloom J, Wiederholt WC (1996) Weight loss precedes dementia in communitydwelling older adults. J Am Geriatr Soc 44, 1147-1152.

[118] White H, Pieper C, Schmader K, Fillenbaum G (1996) Weight change in Alzheimer's disease. J Am Geriatr Soc 44, 265272.

[119] Cronk BB, Johnson DK, Burns JM (2009) Body mass index and cognitive decline in mild cognitive impairment. Alzheimer Dis Assoc Disord, Epub ahead of print.

[120] Burns JM, Johnson DK, Watts A, Swerdlow RH, Brooks WM (2010) Lean mass is reduced in early Alzheimer's disease and associated with brain atrophy. Arch Neurol 67, 428-433.

[121] Loskutova N, Honea RA, Brooks WM, Burns JM (2010) Low volumes of limbic grey matter and the hypothalamus correlate with low bone density in early Alzheimer's disease. J Alzheimers Dis 20, 313-322.

[122] Loskutova N, Honea RA, Vidoni ED, Brooks WM, Burns JM (2009) Bone density and brain atrophy in early Alzheimer's disease. J Alzheimers Dis 18, 777-785.

[123] Burns JM, Mayo MS, Anderson HS, Smith HJ, Donnelly JE
(2008) Cardiorespiratory fitness in early-stage Alzheimer disease. Alzheimer Dis Assoc Disord 22, 39-46.

[124] Burns JM, Cronk BB, Anderson HS, Donnelly JE, Thomas GP, Harsha A, Brooks WM, Swerdlow RH (2008) Cardiorespiratory fitness and brain atrophy in early Alzheimer disease. Neurology 71, 210-216.

[125] Honea RA, Thomas GP, Harsha A, Anderson HS, Donnelly JE, Brooks WM, Burns JM (2009) Cardiorespiratory fitness and preserved medial temporal lobe volume in Alzheimer disease. Alzheimer Dis Assoc Disord 23, 188-197.

[126] Gasparini L, Netzer WJ, Greengard P, Xu H (2002) Does insulin dysfunction play a role in Alzheimer's disease? Trends Pharmacol Sci 23, 288-293.

[127] Craft S, Peskind E, Schwartz MW, Schellenberg GD, Raskind M, Porte D, Jr. (1998) Cerebrospinal fluid and plasma insulin levels in Alzheimer's disease: relationship to severity of dementia and apolipoprotein E genotype. Neurology 50, 164168.

[128] Burns JM, Donnelly JE, Anderson HS, Mayo MS, SpencerGardner L, Thomas G, Cronk BB, Haddad Z, Klima D, Hansen D, Brooks WM (2007) Peripheral insulin and brain structure in early Alzheimer disease. Neurology 69, 10941104

[129] Swerdlow RH (2007) Treating neurodegeneration by modifying mitochondria: potential solutions to a "complex" problem. Antioxid Redox Signal 9, 1591-1603.

[130] Swerdlow RH (2009) Mitochondrial medicine and the neurodegenerative mitochondriopathies. Pharmaceuticals $\mathbf{2}$, $150-167$.

[131] Swerdlow R, Marcus DM, Landman J, Harooni M, Freedman ML (1989) Brain glucose and ketone body metabolism in patients with Alzheimer's disease. Clin Res 37, 461A.

[132] Henderson ST, Vogel JL, Barr LJ, Garvin F, Jones JJ, Costantini LC (2009) Study of the ketogenic agent AC1202 in mild to moderate Alzheimer's disease: a randomized, double-blind, placebo-controlled, multicenter trial. $\mathrm{Nu}$ tr Metab (Lond) 6, 31.

[133] Ghosh S, Patel N, Rahn D, McAllister J, Sadeghi S, Horwitz G, Berry D, Wang KX, Swerdlow RH (2007) The thiazolidinedione pioglitazone alters mitochondrial function in human neuron-like cells. Mol Pharmacol 71, 1695-1702.

[134] Strum JC, Shehee R, Virley D, Richardson J, Mattie M, Selley P, Ghosh S, Nock C, Saunders A, Roses A (2007) Rosiglitazone induces mitochondrial biogenesis in mouse brain. $J$ Alzheimers Dis 11, 45-51.

[135] Onyango IG, Lu J, Rodova M, Lezi E, Crafter AB, Swerdlow RH (2009) Regulation of neuron mitochondrial biogenesis and relevance to brain health. Biochim Biophys Acta 1802, 228-234.

[136] Khan SM, Smigrodzki RM, Swerdlow RH (2007) Cell and animal models of mtDNA biology: progress and prospects. Am J Physiol Cell Physiol 292, C658-669.

[137] Keeney PM, Quigley CK, Dunham LD, Papageorge CM, Iyer S, Thomas RR, Schwarz KM, Trimmer PA, Khan SM, Portell FR, Bergquist KE, Bennett JP, Jr. (2009) Mitochondrial gene therapy augments mitochondrial physiology in a Parkinson's disease cell model. Hum Gene Ther 20, 897-907.

[138] Holmes C, Boche D, Wilkinson D, Yadegarfar G, Hopkins V, Bayer A, Jones RW, Bullock R, Love S, Neal JW, Zotova E, Nicoll JA (2008) Long-term effects of Abeta42 immunisation in Alzheimer's disease: follow-up of a randomised, placebocontrolled phase I trial. Lancet 372, 216-223.

[139] Gilman S, Koller M, Black RS, Jenkins L, Griffith SG, Fox NC, Eisner L, Kirby L, Rovira MB, Forette F, Orgogozo 
JM (2005) Clinical effects of Abeta immunization (AN1792) in patients with $\mathrm{AD}$ in an interrupted trial. Neurology $\mathbf{6 4}$, 1553-1562.

[140] Swanoski MT (2009) Homotaurine: a failed drug for Alzheimer's disease and now a nutraceutical for memory protection. Am J Health Syst Pharm 66, 1950-1953.

[141] Green RC, Schneider LS, Amato DA, Beelen AP, Wilcock G, Swabb EA, Zavitz KH (2009) Effect of tarenflurbil on cognitive decline and activities of daily living in patients with mild Alzheimer disease: a randomized controlled trial.
JAMA 302, 2557-2564

[142] Salloway S, Sperling R, Gilman S, Fox NC, Blennow K, Raskind M, Sabbagh M, Honig LS, Doody R, van Dyck CH, Mulnard R, Barakos J, Gregg KM, Liu E, Lieberburg I, Schenk D, Black R, Grundman M (2009) A phase 2 multiple ascending dose trial of bapineuzumab in mild to moderate Alzheimer disease. Neurology 73, 2061-2070.

[143] Querfurth HW, LaFerla FM (2010) Alzheimer's disease. $N$ Engl J Med 362, 329-344. 